\title{
Stormwater management: methods for measuring near-surface infiltration capacity in clayey till
}

\author{
Britta Bockhorn, Marina Bergen Jensen and Knud Erik S. Klint
}

Glacial till forms a major proportion of the surface deposits in Northern Europe, and in Denmark more than $40 \%$ of the land surface is covered by clayey till. At the same time the majority of densely populated areas are situated on this fertile sediment type. In urban areas, one of the major tools in adaptation to climate change are sustainable drainage systems ( $\mathrm{SuDS}$ ). Their function is to manage the increasing amounts of stormwater on site, often by direct infiltration into the sediment. Accordingly, a realistic estimate of nearsurface hydraulic properties is required when dimensioning SuDS for infiltration.

Clayey tills are generally believed to have a low-bulk hydraulic conductivity and thus a low infiltration capacity. However, clayey tills can be very heterogeneous and especially their bulk hydraulic properties can vary significantly depending on the distribution of permeable structures such as macropores (e.g. earthworm holes and fractures) and sand lenses within the till matrix (Klint \& Gravesen 1999; Nilsson et al. 2001; Kessler et al. 2012). The saturated hydraulic conductivity $\left(\mathrm{K}_{\mathrm{sat}}\right)$ of clayey tills varies from $c .1 .0 \times 10^{-10}$ to $c .1 .0 \times 10^{-4} \mathrm{~m} / \mathrm{s}$ and thus covers a significant span (Fredericia 1990; McKay et al. 1993). Assessment of this value is a major challenge when considering the variability of this sediment type. It is therefore important to determine how representative standard infiltration tests are, specifically in tills, when used to formulate infiltration strategies.

\section{Goals and scope}

In this study we compare three different methods for measuring $\mathrm{K}_{\text {sat }}$ close to the surface: the double ring infiltrometer, the Guelph permeameter and infiltration tests in a small excavation. Each of these methods represents different scales and depths using different flow mechanisms. The goal of the study is to:

1. evaluate the suitability of these methods to return realistic $\mathrm{K}_{\text {sat }}$ values in tills, taking into account the geological heterogeneity of a clayey till from infiltration scale $(0.5 \mathrm{~m} \times 0.5 \mathrm{~m})$ to field scale $(100 \mathrm{~m} \times 100 \mathrm{~m})$, and

2. suggest relevant scales and strategies for infiltration tests in future experiments.
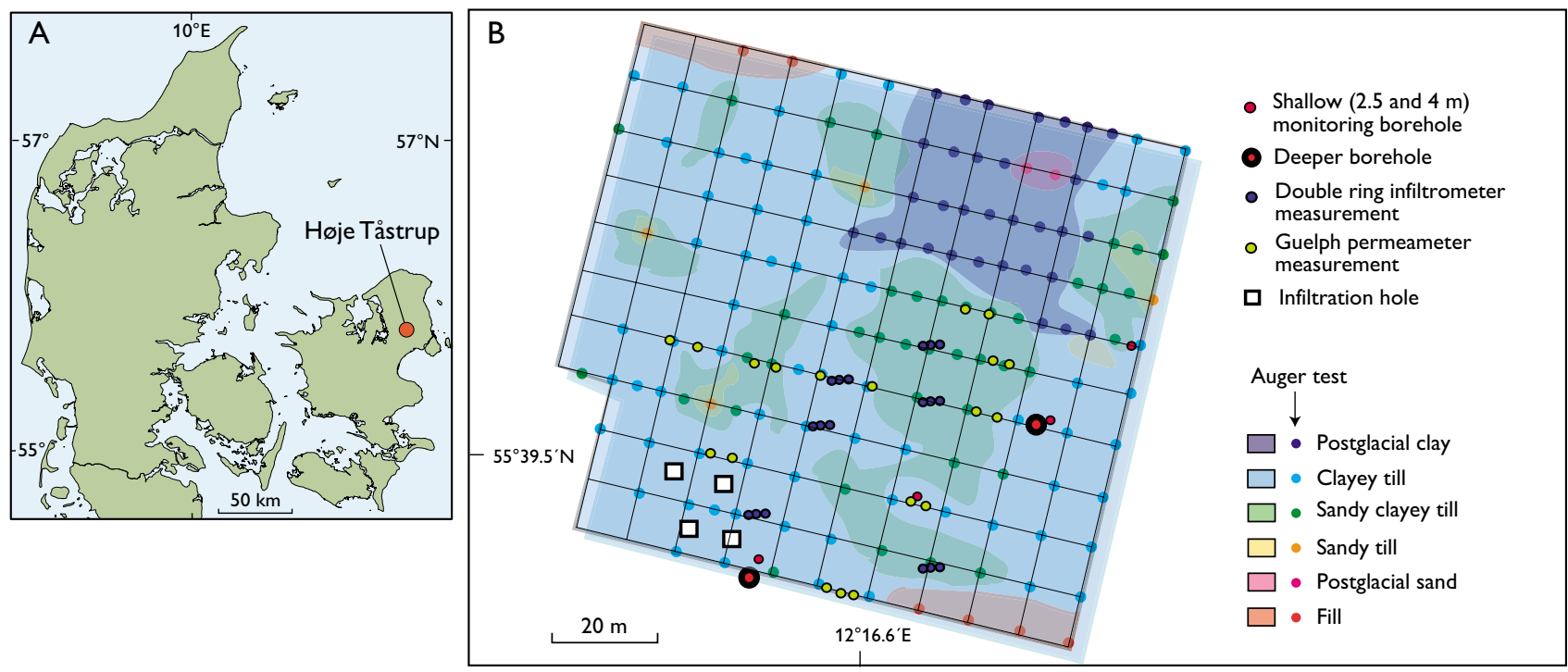

Fig. 1. A: Map of Denmark showing the location of the test site. B: Map of the test site showing the distribution of various sediment types and the locations of the infiltration tests. 


\section{Field experiments}

The infiltration tests were conducted on former agricultural land next to the Technological Institute in Høje Taastrup, Denmark (Fig. 1). The area represents a site with a typical Danish clayey till. The geological setting is dominated by two basal till beds overlying glaciofluvial deposits and flow tills deposited in a supraglacial environment. The glacial deposits overlie highly fractured limestone bedrock $c .14-16 \mathrm{~m}$ below the ground surface. The primary groundwater table is located in the limestone bedrock at depths greater than $16 \mathrm{~m}$ and a secondary groundwater table is found in the upper till unit. The latter is located around $3 \mathrm{~m}$ below the surface during summer and around 1.0 to $0.5 \mathrm{~m}$ below the surface during winter.
An area of $c .100 \mathrm{~m} \times 100 \mathrm{~m}$ was mapped in great detail using a hand auger (Jakobsen $e t$ al. 2011) with sampling in a $10 \times 10 \mathrm{~m}$ grid. Shallow boreholes were cored to depths of $2.5-4 \mathrm{~m}$ and used for monitoring the annual fluctuation of the secondary groundwater table. Two deeper boreholes were cored to a depth of $c .16 \mathrm{~m}$. Two large holes were excavated to 5 and $8 \mathrm{~m}$ below the ground surface and used for detailed mapping of fractures and collection of large, intact samples for hydraulic tests in the laboratory.

The Guelph permeameter method measures the steadystate rate of water flow required to maintain a constant depth of water in a $40 \mathrm{~cm}$ deep and $8 \mathrm{~cm}$ wide cylindrical borehole. Water flows out of the outlet tube through a perforated section located above the permeameter tip. The Guelph

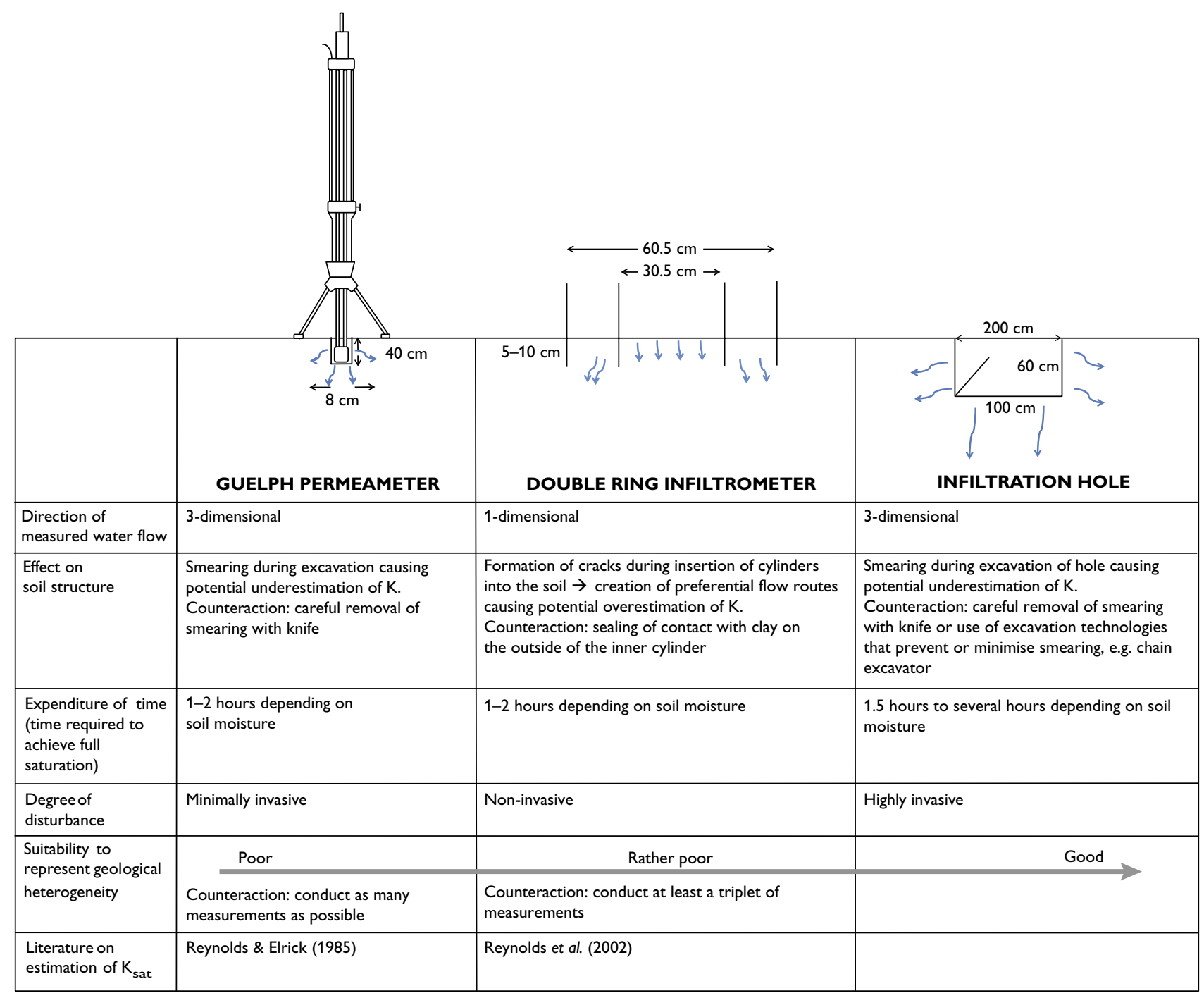

Fig. 2. Overview and principle of the different techniques used in this study. The blue arrows represent water flow. K: hydraulic conductivity. 
permeameter method is based on the assumption of threedimensional steady-state infiltration from a cylindrical test hole into the sediment.

Two concentric metal cylinders with diameters of 30.5 and $60.5 \mathrm{~cm}$ were used for the double ring infiltrometer method. After removal of the sward, the cylinders were carefully pressed $5-10 \mathrm{~cm}$ into the sediment. Water was poured into the inner cylinder, and also into the outer cylinder to prevent lateral movement of water beneath the inner cylinder, thus maintaining one-dimensional flow conditions. The amount of cumulative infiltration with time under fallinghead conditions was recorded and $\mathrm{K}_{\text {sat }}$ values determined.

The infiltration holes were excavated to a depth of $60 \mathrm{~cm}$ with an inner area of $100 \times 200 \mathrm{~cm}$. Smearing caused by the excavation process was carefully removed with a knife. The holes were filled with water and when a steady state was attained, the infiltration rate from the hole into the sediment was measured directly.

A total of 41 infiltration tests were conducted across the site: 19 Guelph permeameter measurements, 18 double ring infiltrometer measurements and four infiltration tests in the excavated holes. More information on the methods is provided in Fig. 2.

\section{Results and discussion}

The application of conventional infiltration technologies indicates that the saturated hydraulic conductivity $\left(\mathrm{K}_{\text {sat }}\right)$ of tills is a spatially highly variable property. In two Guelph permeameter measurements no infiltration at all was observed, which might be due to smearing during preparation of the borehole or compaction by heavy machines as the field site is former agricultural land. Compaction might also be the reason for one no-flow measurement in the double ring infiltrometer.

The results are presented in Table 1 and Fig. 3. The Guelph permeameter and the double ring infiltrometer average values are lower than those from the infiltration holes. This is probably due to not fully saturated conditions around the holes as the area is rather large compared to the area used for the Guelph permeameter and double ring infiltrometer measurements, where saturated conditions are attained reasonably quickly. The fact that the holes involve a much larger

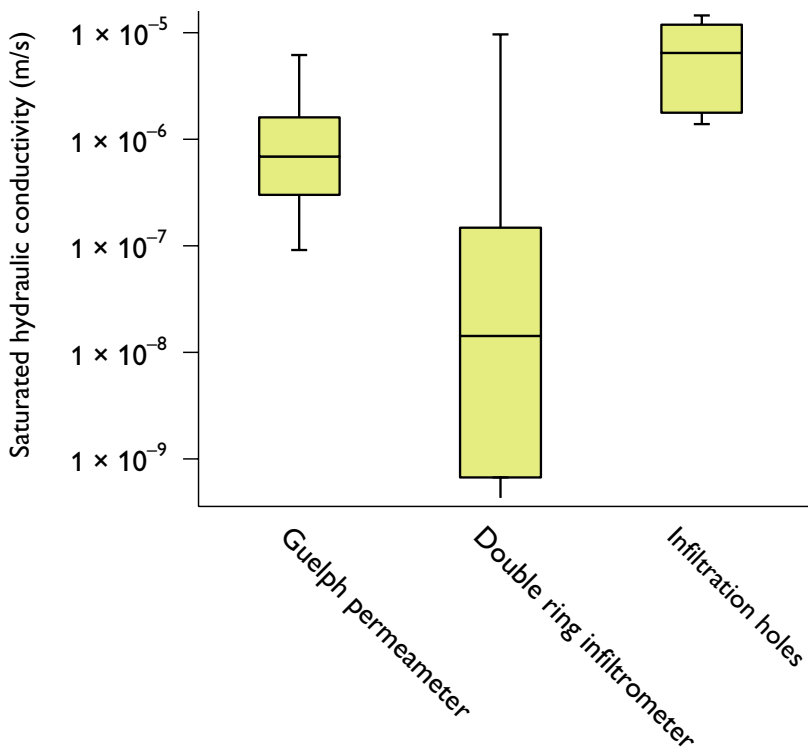

Fig. 3. Box and whisker diagram illustration of the range of saturated hydraulic conductivity values obtained using the Guelph permeameter, double ring infiltrometer and infiltration hole techniques. The scale is logarithmic. Whiskers are plotted at the maximum and minimum values, however, the minimum value for the double ring infiltrometer test is below the scale and not shown.

area than the Guelph permeameter and the double ring infiltrometer means that they involve more than one sediment type and accounts best for macro-pores, confirming that geological heterogeneity on clayey till plains influences the hydraulic conductivity even at infiltration plot scales.

A realistic estimate of hydraulic conductivity is crucial when planning how to manage stormwater infiltration. The present field-based study shows that hydraulic conductivity values are strongly influenced by the physical scale of the field measurements. This is mainly due to the local distribution of macro-pores and how well the geological heterogeneity is represented. The importance of scale-dependent variability of $\mathrm{K}_{\text {sat }}$ has also been demonstrated in previous studies (e.g. Jenssen 1990; Ronayne et al. 2012), but is still widely neglected when hydraulic conductivity values are used for stormwater management practices.

Due to the large variation of grain-size distribution in tills, it is not recommended to apply methods that define $\mathrm{K}_{\text {sat }}$ based on grain-size distribution. Neither is it recommended

Table 1. Summary statistics of saturated hydraulic conductivity values

\begin{tabular}{|c|c|c|c|c|}
\hline Method & Number & Mininum & Maximum & Arithmetic mean \\
\hline Guelph permeameter & 19 & $9.12 \times 10^{-8}$ & $6.18 \times 10^{-6}$ & $1.44 \times 10^{-6}$ \\
\hline Double ring infiltrometer & 18 & $7.43 \times 10^{-13}$ & $9.7 \times 10^{-6}$ & $8.26 \times 10^{-7}$ \\
\hline Infiltration holes & 4 & $1.4 \times 10^{-6}$ & $1.46 \times 10^{-5}$ & $7.25 \times 10^{-6}$ \\
\hline
\end{tabular}


to use $\mathrm{K}_{\text {sat }}$ values obtained with a double ring infiltrometer or a Guelph permeameter alone as they can vary by several orders of magnitude already on a infiltration plot scale. In our study we found a variable of more than two orders of magnitude. Data from infiltration holes give more realistic values. However, they are highly invasive and it may be difficult to excavate adequate holes in densely populated areas.

Instead of using highly invasive infiltration holes, we recommend to carry out combined hydrogeological investigations where double ring infiltrometer and Guelph permeameter measurements are supported by geological information from maps of near-surface deposits and borehole descriptions. In that less-destructive way, small-scale geological heterogeneity can be revealed and the most suitable areas for stormwater infiltration can be selected to enhance work efficiency of infiltration devices.

\section{Acknowledgement}

The work was conducted as part of the innovation consortium Cities in Waterbalance (Byer i Vandbalance) financed by the Danish Council for Technology and Innovation.

\section{References}

Fredericia, J. 1990: Saturated hydraulic conductivity of clayey tills and the role of fractures. Nordic Hydrology 21, 119-132.

Jakobsen, P.R., Hermansen, B. \& Tougaard, L. 2011: Danmarks digitale jordartskort. Danmarks og Grønlands Geologiske Undersøgelse Rapport 2011/40, $28 \mathrm{pp}$.
Jenssen, P.D. 1990: Methods for measuring the saturated hydraulic conductivity of tills. Nordic Hydrology 21, 95-106.

Kessler, T.C., Klint, K.E.S., Nilsson, B. \& Bjerg, P.L. 2012: Characterization of sand lenses embedded in tills. Quaternary Science Reviews 53, $55-71$.

Klint, K.E.S. \& Gravesen, P. 1999: Fractures and biopores in Weichselian clayey till aquitards at Flakkebjerg, Denmark. Nordic Hydrology 30, 267-284.

McKay, L.D., Cherry, J.A. \& Gillham, R.W. 1993: Field experiments in a fractured clay till. 1. Hydraulic conductivity and fracture aperture. Water Resources Research 29, 1149-1162.

Nilsson, B., Sidle, R.C., Klint, K.E., Bøggild, C.E. \& Broholm, K. 2001: Mass transport and scale-dependent hydraulic tests in a heterogeneous glacial till-sandy aquifer system. Journal of Hydrology 243, 162-179.

Reynolds, W.D. \& Elrick, D.E. 1985: In situ measurement of field-hydraulic conductivity, sorptivity, and the alpha-parameter using the Guelph permeameter. Soil Science 140, 292-302.

Reynolds, W.D., Elrick, D.E., Youngs, E.G., Amoozegar, A., Booltink, H.W.G. \& Bouma, J. 2002: Saturated and field-saturated water flow parameters. In: Dane, J.H. \& Topp, G.C. (eds): Methods of soil analysis, Part 4, Physical methods, 797-878. Madison, Wi: Soil Science Society of America.

Ronayne, M.J., Houghton, T.B. \& Stednick, J.D. 2012: Field characterization of hydraulic conductivity in a heterogeneous alpine glacial till. Journal of Hydrology 458-459, 103-109.

\footnotetext{
Authors' addresses

B.B. \& M.B.J., Department of Geosciences and Natural Resource Management, University of Copenhagen, Rolighedsvej 23, DK-1958 Frederiksberg, Denmark.E-mail:bboc@ign.dk.ku

K.E.S.K., Geological Survey of Denmark and Greenland, Øster Voldgade 10, DK-1350 Copenhagen K, Denmark.
} 